\title{
SISMIKO: emergency network deployment and data sharing for the 2016 central Italy seismic sequence
}

\author{
Milena Moretti*, Silvia Pondrelli*, LuCia MARgheriti*, Luigi AbruZZeSE*, MARio ANSElmi*, \\ PierRe ARROUCAU ${ }^{\circ}$, PAOlA BACCHESCHI $^{*}$, BRIAN BAPTIE $^{\circ}$, RAFFAELE BONADIO $^{\circ}$, ANDREA BONO*$^{*}$, \\ Augusto BuCCI*, MAuro ButTinelli*, MARCO CAPELlO*, VinCENZO CARDinAlE ${ }^{*}$, ANGELO \\ CASTAGNOZZI*, MARCO CATTANEO*, GIANPAOLO CECERE* , ClAUDIO CHIARABBA*, LAURO

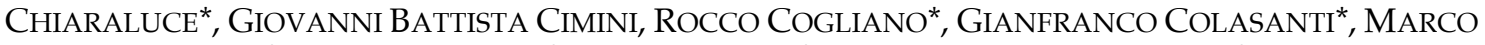 \\ COLASANTI*, FABIO CRISCUOLI*, EZIO D’ AlEMA* ${ }^{*}$, ANTONINO D' AlESSANDRO* , CIRIACO

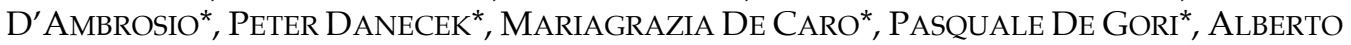 \\ Delladio*, Gaetano De LUCA*, GIOVANni De LUCA*, MARTINA DEMARTiN*, MARIA Di NeZZA*, \\ RAFFAELE DiSTEFANO*, LUIGI FALCO*, MASSIMO FARES* ${ }^{*}$, MASSIMO FRAPICCINI* ${ }^{*}$ AlBERTO FREPOLI*, \\ DANILO GALLUZZO*, EDOARDO GIANDOMENICO*, LUCIAN GIOVANI*, CARLO GIUNCHI* ALADINO \\ GOVONI $^{*}$, DAVID HAWTHORN ${ }^{\circ}$, CHIARA LADINA $^{*}$, VALENTINO LAUCIANI $^{*}$, ANTHONY LINDSAY $^{\circ 0}$, \\ SIMONE MANCINI*, AlFONSO GIOVANNI MANDIELLO ${ }^{*}$, SiMONE MARZORATI*, MARCO MASSA*, \\ ANTONINO MEMMOLO*, FRANCO MIGLIARI*, FELICE MiNICHIELlO* , GIANCARLO MONACHESI*,

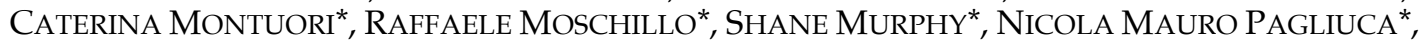 \\ MARINA PASTORI*, DAVIDE PICCININI*, UlDERICO PICCOLINI*, STEFANO PINTORE* ${ }^{*}$ GIULIO POGGIALI ${ }^{\circ}$, \\ SANDRO RAO*, GILBERTO SACCOROTTI*, MARGARITA SEGOU ${ }^{\circ}$, ANDREA SERRATORE*, MARCELlO \\ SILVESTRI*, STEFANO SILVESTRI ${ }^{*}$, MASSIMILIANO VALLOCCHIA ${ }^{*}$, LUISA VALOROSO ${ }^{*}$, LUCIANO \\ ZUCCARELLO*, ALbERTO MiCHELINI* AND SALVATORE MAZZA* \\ *Istituto Nazionale di Geofisica e Vulcanologia, Italy \\ ${ }^{\circ}$ Dublin Institute for Advanced Studies, Ireland \\ ${ }^{\circ}$ British Geological Survey, United Kingdom \\ ${ }_{\circ \circ}$ University of Ulster, United Kingdom \\ milena.moretti@ingv.it
}

\begin{abstract}
At 01:36 UTC (03:36 local time) on August 24th 2016, an earthquake Mw 6.0 struck an extensive sector of the central Apennines (coordinates: latitude $42.70^{\circ} \mathrm{N}$, longitude $13.23^{\circ} \mathrm{E}, 8.0 \mathrm{~km}$ depth). The earthquake caused about 300 casualties and severe damage to the historical buildings and economic activity in an area located near the borders of the Umbria, Lazio, Abruzzo and Marche regions. The Istituto Nazionale di Geofisica e Vulcanologia (INGV) located in few minutes the hypocenter near Accumoli, a small town in the province of Rieti. In the hours after the quake, dozens of events were recorded by the National Seismic Network (Rete Sismica Nazionale, RSN) of the INGV, many of which had a ML > 3.0. The density and coverage of the RSN in the epicentral area meant the epicenter and magnitude of the main event and subsequent shocks that followed it in the early hours of the seismic sequence were well constrained. However, in order to better constrain the localizations of the aftershock hypocenters, especially the depths, a denser seismic monitoring network was needed.

Just after the mainshock, SISMIKO, the coordinating body of the emergency seismic network at INGV, was activated in order to install a temporary seismic network integrated with the existing permanent network in the epicentral area. From August the 24th to the 30th, SISMIKO deployed eighteen seismic stations, generally six components (equipped with both velocimeter and accelerometer), with thirteen of the seismic station transmitting in real-time to the INGV seismic monitoring room in Rome. The design and geometry
\end{abstract}


of the temporary network was decided in collaboration with other groups who were deploying seismic stations in the region, namely EMERSITO (a group studying site-effects), and the emergency Italian strong motion network (RAN) managed by the National Civil Protection Department (DPC). Further 25 BB temporary seismic stations were deployed by colleagues of the British Geological Survey (BGS) and the School of Geosciences, University of Edinburgh in collaboration with INGV.

All data acquired from SISMIKO stations, are quickly available at the European Integrated Data Archive (EIDA). The data acquired by the SISMIKO stations were included in the preliminary analysis that was performed by the Bollettino Sismico Italiano (BSI), the Centro Nazionale Terremoti (CNT) staff working in Ancona, and the INGV-MI, described below.

\section{INTRODUCTION}

ISMIKO is an operational group in the Istituto Nazionale di Geofisica e Vulcanologia (INGV) which coordinates all the seismic emergency networks of INGV (Fig. 1). The staff involved in this group come from the different sections within the INGV which deal with seismic monitoring on a daily basis [Moretti et al. 2016]. The aim of SISMIKO is to deploy additional seismic stations in a region following a significant earthquake. Increasing the density of a seismic monitoring network, during a seismic sequence following a significant earthquake has the effect of improving the detection capabilities of the network and the precision of the earthquake locations. This in turn allows for the definition the geometry of the activated fault structures and to constrain the spatial distribution of the seismicity, moreover it provides high quality data for hazard and seismotectonic studies and investigations into the physics of earthquakes.

SISMIKO deals with important decisions, procedures and actions that the INGV undertakes during a seismic emergency, in cooperation with other emergency groups like EMERSITO, who study site effects [Cultrera et al. 2016]; QUEST, which is involved in damage relief (QUick Earthquake Survey Team [QUEST working group 2016]); EMERGEO, which focuses on mapping geological surface effects [EMERGEO Working Group 2016]; and IES [Nostro at al. 2011] who provide an information service for the general public (Information in emergency earthquake).
Following the formalization of these INGV emergency groups, a training test of the protocols for the different individual emergency groups was organized on 26th November 2015 [Pondrelli et al. 2016]. The lessons learnt during this training test helped the coordination of the different INGV groups to handle the central Italy emergency.

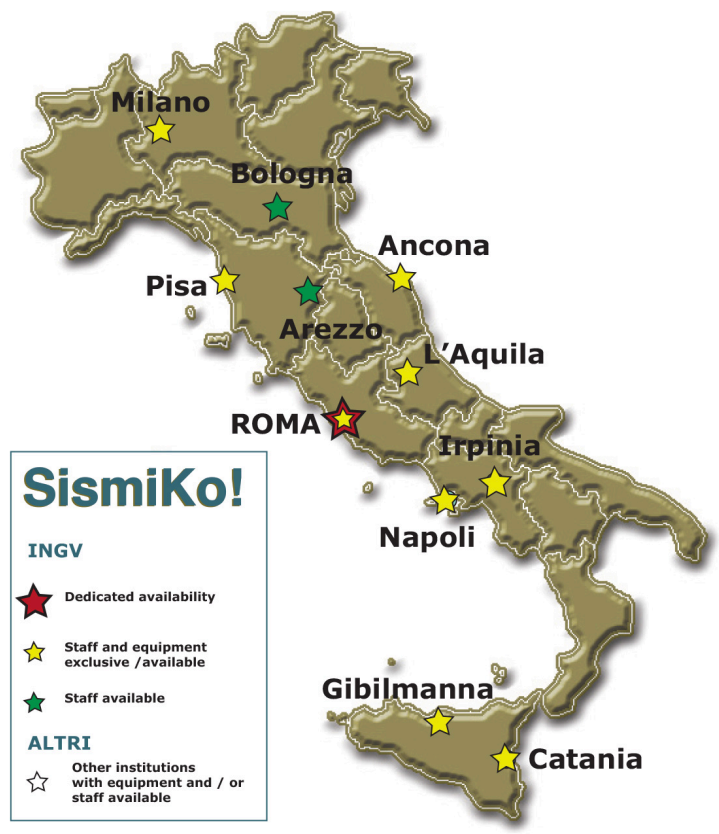

Figure 1: INGV offices that are involved in the SISMIKO group with equipment and/or personnel that is available for emergency response.

\section{TIMING OF THE DEPLOYMENT}

The Mw 6.0 Amatrice event occurred on August 24, 2016 it was recorded by INGV National Seismic Network (Rete Sismica Nazionale, RSN, 
http: / / doi.org/10.13127/SD/X0FXNH7QFY), and the epicenter was located near the village of Accumoli at a depth of $8 \mathrm{~km}$ (http: / / cnt.rm.ingv.it/7073641). As per protocol in the INGV for emergency events, the national SISMIKO coordinators received an SMS with preliminary information about the earthquake a few minutes after the origin time of the event. The alert was then forwarded to local representatives of SISMIKO group and the coordination for the deployment of an emergency seismic network commenced.

After checking the performance of the permanent stations of the RSN in the epicentral area and taking into account the trend of the initial aftershocks, the SISMIKO group prepared, in less than three hours from the mainshock, the theoretical distribution of the deployment to guide the teams on the field.

On the first day of activation of the SISMIKO group personnel in the INGV offices closest to the epicentral area were used: Ancona (1 team), Grottaminarda (2 teams), L'Aquila (1 team) and Rome (1 team), in total fourteen people were in the field and ten stations were deployed. The team from Ancona, reached the epicentral area at around 7:15 UTC, and installed three temporary stations each one equipped with one velocimetric sensor and one accelerometer in the northern and eastern side of the initial aftershock sequence. The first installation was completed at around 08:40 UTC (i.e. station T1243). This station, as well as station T1241 (which start recording at around 11:15 UTC) and station T1242 (14:40 UTC), were in UMTS realtime transmission. INGV personnel based in Grottaminarda organized two teams to go in the field for maintenance of the permanent seismic stations that were part of the RSN and for the installation of temporary stations. This group installed three temporary stations located near Amatrice, one equipped with an accelerometer, one with a short period seismometer and the other with Broad Band (BB). The first temporary station installed, T1201 was completed around 15:30 UTC, after this T1202 and T1204 were positioned; all stations are in UMTS real-time transmission. INGV Rome contributed to the deployment with four stations in local acquisition, each equipped with a short period seismometer and an accelerometer. These stations were installed on western side of the seismic sequence. The first installation by the
Rome group was station T1211 at about 7:30 UTC and was located on the road which leads from Rome to the epicentral area; T1212, T1213 and T1214 were deployed in the following hours.

During the day of August 24th the Grottaminarda, L'Aquila and Ancona staff performed maintenance on stations AQT1, NRCA, SMA1 and LNSS (Fig. 2), in the RSN, which had experienced electrical power and data transmission problems due to collapses and damages in the epicentral area, in the initial hours after the main earthquake.

In the next two days, six teams from Ancona (1), Grottaminarda (2), L'Aquila (1) and Rome (2), continued the field work. Five additional stations were installed, of which two were in realtime, moreover the teams visited the stations that were operating in local acquisition mode where they downloaded the data.

Looking at the evolution of the seismicity in the evening of August 26 it was decided a further improvement to the network in the southern sector was required. On Sunday 28 a team of INGV Pisa installed two Broad Band stations (BB) (T1246 and T1247).

On August 30 station T1299 was the final station installed in the temporary network by the INGV Roma RSN staff. The station, equipped with a short period velocimeter and an accelerometer, transmitted data in real-time via satellite connection, it was deployed in the village Casale Bucci, close Amatrice, in the southern sector of the sequence.

Similar to the Emilia emergency in 2012 [Moretti et al. 2012; 2013], there has been a continuous interaction with EMERSITO (Fig. 2, fuchsia hexagons) and with the mobile network group of the Italian Strong Motion Network (RAN-DPC, http://ran.protezionecivile.it/; Fig. 2, orange hexagons) for the sharing of information in order to integrate the different temporary networks without redundant overlapping. In addition, at the start of September colleagues of the British Geological Survey (BGS) and the School of Geosciences at the University of Edinburgh arrived in the epicentral area. The INGV was in contact with these two groups since the start of the seismic emergency when they had expressed interest in deploying a Broad Band network (BB) to supplement the INGV-SISMIKO network in region. Thus, as in the 1997-98 seismic sequence in Umbria [Amato 
et al. 1998] and in 2009 in Abruzzo [Margheriti et al. 2011], and in Emilia 2012 [Moretti et al. 2012] we welcomed this international collaboration between European research institutes. This collaboration resulted in two weeks of fieldwork starting at the beginning of September, has led to the installation of an additional $25 \mathrm{BB}$ seismic stations (Fig. 2, blue hexagons). The installation of these stations, which remained in acquisition for a period of about 6 months and whose data will be available on the web site of the Incorporated Research Institutions for Seismology

(IRIS;

http://ds.iris.edu/ds/nodes/dmc/). These extra stations have enabled us to halve the interdistance between seismic stations from approximately $15-18 \mathrm{~km}$ to $6-8 \mathrm{~km}$ (see Fig. 2).
In Fig. 3, shows the timing of installation and maintenance of temporary network SISMIKO during the first emergency month. In the tables in Annex A, the list of installed stations and the type of instrumentation used.

At the end of October 2016, on the 30th the strongest earthquake of the sequence $\mathrm{Mw}=6.5$, stoke again the same area, this event was preceded by two earthquakes of magnitude greater than 5.0 on October the 26th, the total length of the fault system interested by the seismicity is now about $55 \mathrm{~km}$. After these events, SISMIKO has installed 4 new temporary stations in the area north of the sequence (Fig. 2, orange triangles).

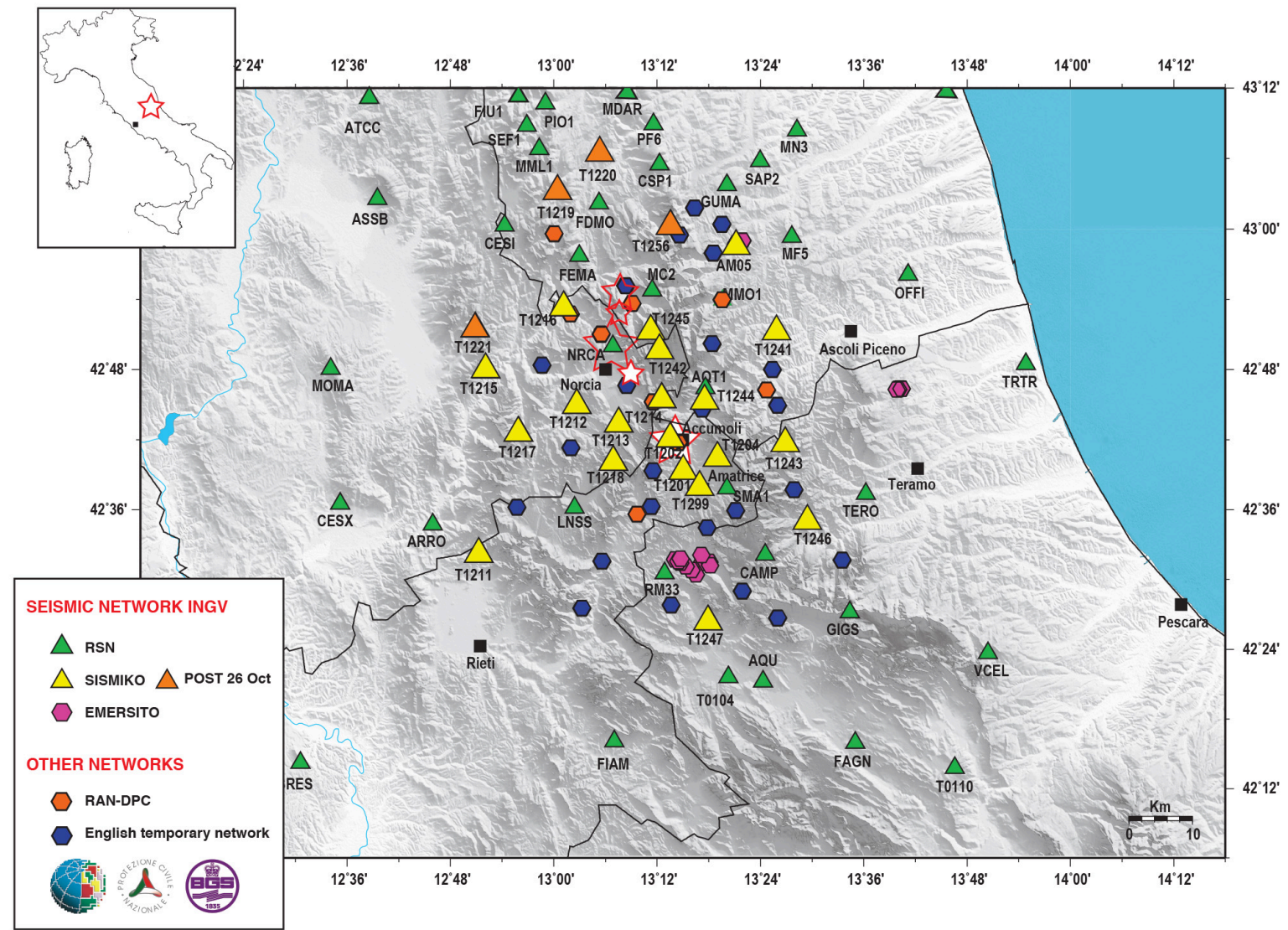

Figure 2: Map of the seismic stations deployed after August 24th: INGV permanent stations (green triangles) and SISMIKO temporary stations (yellow triangles), EMERSITO stations (fuchsia hexagons), RAN-DPC stations (orange hexagons) and the BB network (blue hexagons). The orange triangles are seismic stations deployed after the events October 26th. The stars show the strongest earthquakes of the sequence up to the submission of the paper: the full stars shows those at end of August, the stars empty at end of October. 


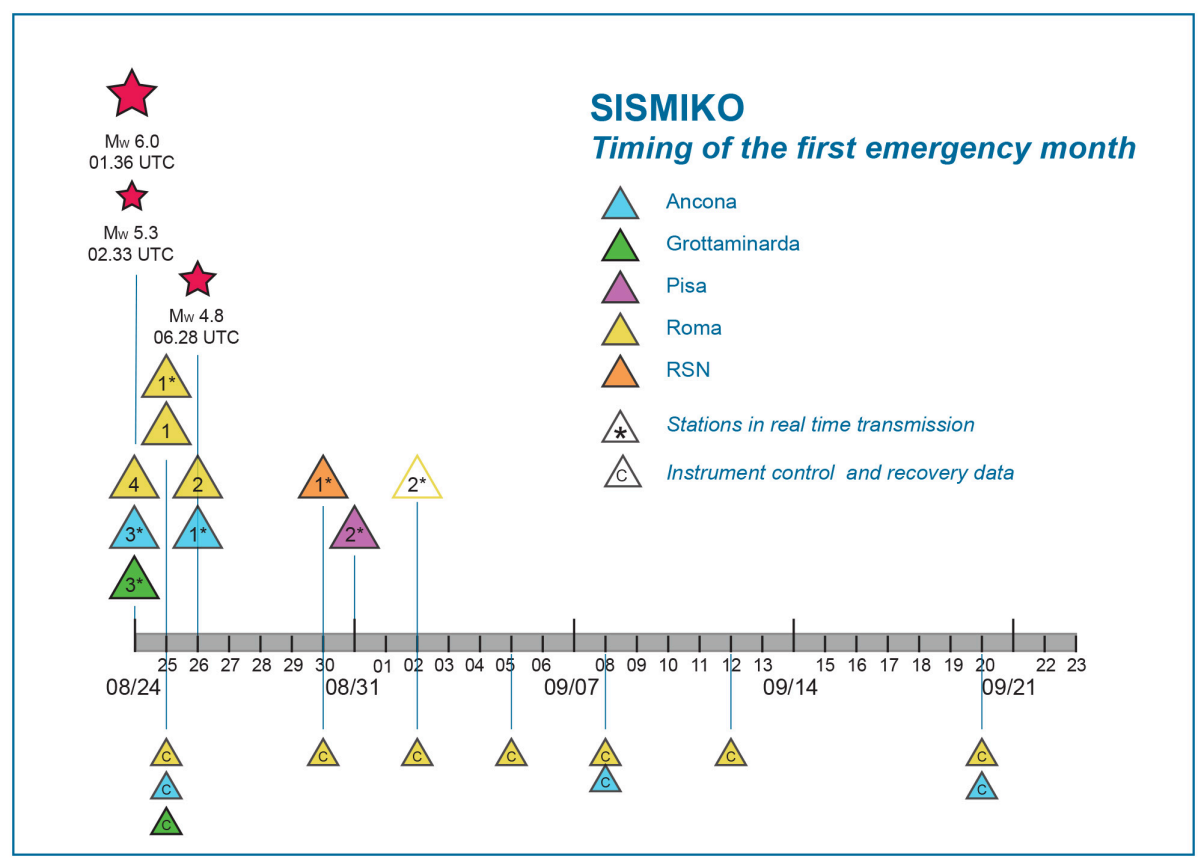

Figure 3: Timing of installation and maintenance of temporary network SISMIKO during the first emergency month. Red stars show the strongest earthquakes of the sequence. The numbers inside the triangles, in different colours, depending on the INGV office which carried out the activities, indicating the stations installed throughout the day. With an asterisk are the ones highlighted in real-time transmission and, in the case of stations T1216 and T1217, initially in local acquisition, and then subsequently have been equipped with UMTS router (September 2). The triangles in the lower part of the timeline indicating when it was controlled instrumentation and were collected of data.

\section{PRELIMINARY ANALYSIS OF THE DATA ACQUIRED BY SISMIKO STATIONS}

The mainshock was followed by sustained seismic activity; in the first month after the main event there have been about 12,000 events, including $16 \mathrm{ML} \geq 4.0$ (Fig. 4). All data collected by the stations installed by SISMIKO, are available at the European Integrated Data Archive (EIDA; http:/ / eida.rm.ingv.it/ [Mazza et al. 2012]). The inclusion in the EIDA of waveforms was done immediately at the deployment of the stations, while the integration of data in the surveillance system at the INGV headquarters in Rome was gradual; in fact, during an emergency the surveillance room has the duty of alerting DPC and the technical operations needed to allow stations in the automatic location system should be done with extreme caution. Starting from September 9, 2016, in weekly steps, data from the SISMKO stations recording in local acquisition were collected; converted and published in the international Standard for Exchange of Earthquake data (SEED) format and archived in in EIDA [Mazza et al. 2012]. The availability of real-time data from the temporary stations allowed for the analysis of the seismic sequence in almost real-time with quality and accuracy.

On the morning of August 24, the first stations that broadcast real-time data from the epicentral area were T1242, T1243 and T1244. There data was first transmitted to the servers in the Ancona office, and in short time were incorporated into the automatic analyzes of the ongoing seismic activity. In particular, station T1243 was used for the first time in the automatic location of an event at 08:45:30 UTC; stations T1241 and T1242 at 11:20:36 UTC and 14:42:59 UTC respectively. At the same time station 
T1243 was also integrated in the seismic monitoring system in the Rome office and used for the first time in the event of ML 3.1 of 15:39:32 UTC [http://cnt.rm.ingv.it/event/7116751]. At the same time as station T1243 was included in the central seismic monitoring system an additional two permanent stations of the Marche
Regional network, managed by INGV headquarters in Ancona was incorporated into the network. The two stations, MC2 and MMO1 (Fig. 2) before the emergency were not acquired by INGV-Rome but after the mainshock were included for the good coverage that guaranteed in the area North and Northeast of the sequence.

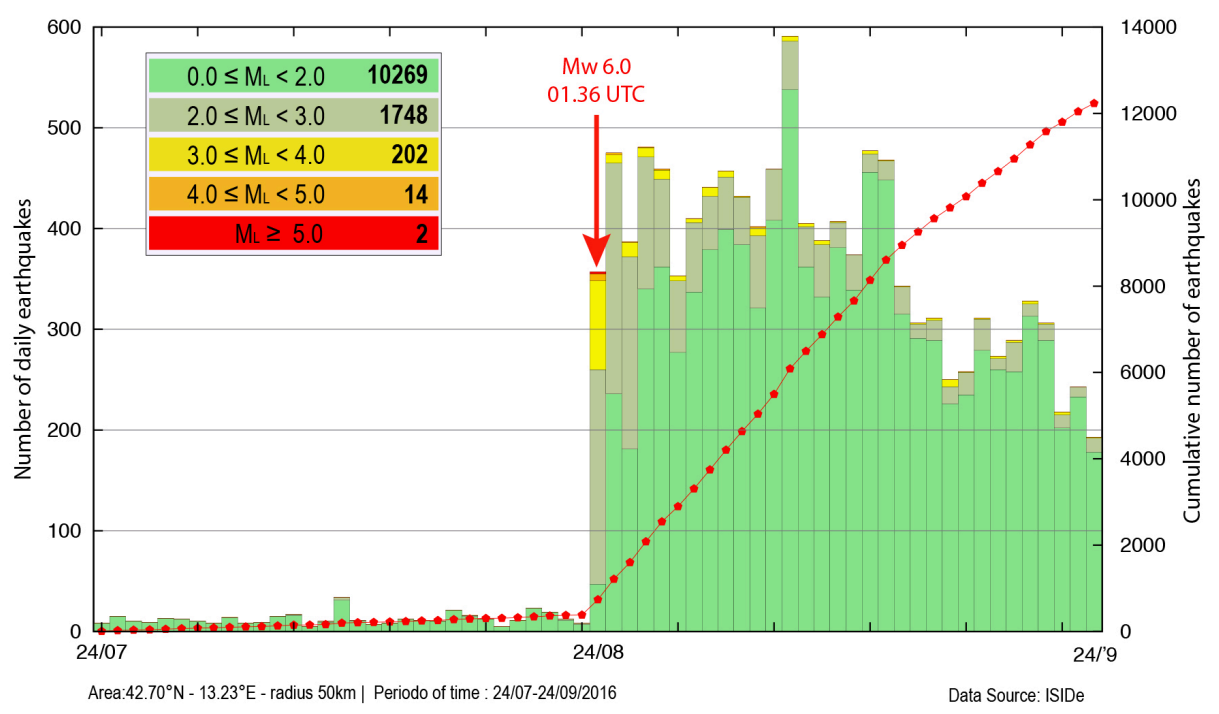

Figure 4: Evolution of seismic activity in the area of the seismic sequence in the first month of seismic activity and the month immediately preceding. The selection of events was made in a circular area of $50 \mathrm{~km}$ centered in the mainshock $\left(42.70^{\circ} \mathrm{N}-13: 23^{\circ} \mathrm{E}\right)$. The figure shows the locations produced by seismologists on duty at the INGV seismic monitoring center in Rome.

There are several advantages associated with the integration of temporary stations in the analysis of data that were observed in the initial hours of the emergency. The thirteen temporary stations that transmitted in real-time were gradually added in the seismic monitoring system making it possible to lower the detection threshold of the network and improve the quality of the hypocenter determinations especially as regards to the depth of the hypocenters. To evaluate the contribution of the SISMIKO temporary network to locate local seismicity in the Amatrice area, we have applied the Seismic Network Evaluation through Simulation (SNES) method [D'Alessandro et al. 2011] to two different network that are the RSN and the RSN+SISMIKO. The SNES method allows de- termining, as a function of magnitude, hypocentral depth and confidence level, the spatial distribution of the number of active stations in the location procedure and their relative azimuthal gap and the confidence levels of hypocentral parameters (see Annex B).

Data relayed in real-time together with data from temporary stations in local acquisition (i.e. stations T1211-12-13-14-18 and 16-17), represented a major contribution in the localization of earthquakes for the Italian Seismic Bulletin (BSI) [Nardi et al. 2015]; BSI is reviewing the sequence with two main goals: a) improve as mentioned the location of aftershocks detected by the automatic system and b) insert into catalogue events not localized by the seismologist on shifts in the surveillance room. More details can be found in the "Preliminary report on the 
activities carried out by the Italian Seismic Bulletin Group [Bollettino Sismico Italiano Gruppo di lavoro Amatrice (2016); Marchetti et al. 2016].

The proximity of the area affected by the seismic earthquake sequence in relation to the area monitored by INGV Ancona office allowed us to use automatic procedures, to make automatic quality control analysis [Marzorati et al. 2012] on the real-time data.

Moreover, the continuous band-pass filtered signals are analyzed by the STA/LTA trigger algorithm to detect triggers at each station, an event is declared when a trigger is detect at a number of key stations. In particular, event declaration is controlled by the weights assigned to each individual component of the seismic stations on the basis of their average noise level to enhance the influence of the best stations. This procedure allows the maintenance of low STA/LTA ratios (and thus high sensitivity) without increasing too much the probability of false events declaration due to triggering occurring by chance. The core of the automatic system is the RSNI-Picker [Spallarossa et al. 2014; Scafidi et al. 2016]. This picker uses the "Akaike information criterion" (AIC; Akaike, 1974), which strongly limits the occurrence of false pickings. Moreover, a user-calibrated procedure assigns to each picking a weight that attempts to mimic a human operator. This procedure has automatically located 4174 events between the 24th and 31st August, and 7245 events between the 1st and 20th September.

Moreover, from August 24th, 2016 (01:36:32 UTC) to 30th September 2016 (last update) the accelerometric database of the INGV (http://ismd.mi.ingv.it/; [ISMD Working Group 2016]), analyzed and published in near real-time over 21,300 waveforms belonging to about 121 earthquakes with a magnitude range between 3.0 and 6.0. In particular, about 1600 accelerometer recordings are relative only to stations installed in the epicentral area by SISMIKO. All the real-time accelerometer data from the SISMIKO stations (see Table 2 in Annex A) are available after 1 or 2 hours since the origin time of each earthquake, in SAC and ASCII formats. For each earthquake, there is 5 minutes of signal from the origin time determined by the monitoring room in Rome and published on the CNT website (cnt.rm.ingv.it). Details on the automatic data and analysis method are described in Massa et al. [2014].

\section{ACKNOWLEDGEMENTS}

We do thank the many people who contributed to the success of the seismic rapid-response in the earthquake area in Amatrice. We are grateful to Elisa Zambonelli and other DPC colleagues for coordinating with us during the deployment. The study benefited from funding provided by the Italian Presidenza del Consiglio dei Ministri, Dipartimento della Protezione Civile (DPC); scientific papers funded by DPC do not represent its official opinion and policies.

\section{REFERENCES}

Amato, A. et al. (1998). The Colfiorito, UmbriaMarche earthquake sequence in central Italy (Sept.-Nov., 1997): a first look to mainshocks and after- shocks, Geophys. Res. Lett. 25, 28612864.

BOLLETTINO SISMICO ITALIANO - Gruppo di lavoro Amatrice (2016). Rapporto preliminare sulle attività svolte dal gruppo bollettino sismico italiano a seguito del terremoto di Amatrice Mw 6.0 ( 24 agosto 2016, italia centrale). Doi: 10.5281/ zenodo.157545.

D'Alessandro, A., Papanastassiou, D., Baskoutas, I. (2011). Hellenic Unified Seismological Network: an evaluation of its performance through SNES method, Geophysical Journal Int., 185, 3, 1417-1430. Doi: 10.1111/j.1365246X.2011.05018.x.

EMERGEO Working Group (2016). Coseismic effects of the 2016 Amatrice seismic sequence: first geological results, Ann. Geophyiscs, this issue. DOI: 10.4401 / ag-7195.

Cultrera G., D'Alema E., Amoroso S., Angioni B., Bordoni P. , Cantore L. , Cara F., Caserta A., Cogliano R., D'Amico M., Di Giulio G., Di Naccio D., Famiani D., Felicetta C., Fodarella A., Lovati S., Luzi L., Mascandola C., Massa M., Mercuri A., Milana G., Pacor F., Pischiutta M., Pucillo S., Puglia R., Riccio G., Tarabusi G., 
Vassallo M. (2016). Site effect studies following the $2016 \mathrm{Mw}$ 6.0 Amatrice Earthquake (Italy): the Emersito Task Force activities, Ann. Geophyiscs, this issue.

ISMD Working Group (2016). INGV Strong Motion database: Dati accelerometrici INGV in tempo quasi reale.

https: / / sites.google.com/a/ingv.it/datiemergenza/attivita-scientifiche/ground-motion. Doi: $10.5281 /$ zenodo.154703.

Marchetti, A. et al. (2016). The Italian Seismic Bulletin: strategies, revised pickings and locations of the Amatrice seismic sequence, Ann. Geophyiscs, this issue. DOI: 10.4401/ag-7169.

Margheriti, L. et al. (2011). Rapid response seismic networks in Europe: lessons learnt from the L'Aquila earthquake emergency, Ann. Geophys., 54 (4). Doi: 10.4401/ag-4953.

Marzorati, S., Carannante, S., Cattaneo, M., D'Alema, E., Frapiccini, M., Ladina, C., Monachesi G., and Spallarossa. D. (2012). Automated control procedures and first results from the temporary seismic monitoring of the 2012 Emilia sequence. Ann. Geophys., 55 (4); doi:10. 4401/ag-6116.

Massa, M., Lovati, S., Franceschina, G., D'Alema, E., Marzorati, S., Mazza, S., Cattaneo, M., Selvaggi, G., Amato, A., Michelini, A. and Augliera. P. (2014). ISMD, a web portal for the realtime processing and dissemination of INGV strong-motion data, Seism. Res. Letters, $85,4,727-734$

Mazza, S., Basili, A., Bono, A., V., Lauciani, Mandiello, A.G., Marcocci, C., Mele, F.M., Pintore, S. M. Quintiliani, L., Scognamiglio and G. Selvaggi (2012). AIDA - Seismic data acquisition, processing, storage and distribution at the National Earthquake Center, INGV, Ann. Geophys., 55 (4). Doi:10.4401/ag6145.

Moretti, M. et al. (2012). Rapid-response to the earthquake emergency of May 2012 in the Po Plain, Northern Italy, Ann. Geophys., 55 (4), 583 - 590. Doi: 10.4401/ag-6152.

Moretti, M., et al. (2013). Terremoto in Emilia: le attività del Pronto Intervento Sismico durante il primo mese di emergenza. Modalità e tempistica, Quaderni di Geofisica, 110.

Moretti, M., Margheriti, L., Govoni, A. (2016). Rapid response to earthquake emergencies in Italy: temporary seismic network coordinated deployments in the last five years, in: D'Amico S. (Ed): Earthquakes and their impacts on Society, Springer.

Nardi, A. et al. (2015). Bollettino Sismico Italiano: novità, $34^{\circ}$ GNGTS, Trieste, novembre 2015.

Nostro, C., Camassi, R., Crescimbene, M., La Longa, F., Ercolani E. et al. (2011). Emergenza e informazione, estratto da "Sintesi dei lavori del Workshop. EDURISK 2002 - 2011 | 10 anni di progetti di educazione al rischio", Miscellanea INGV, 13.

Pintore, S., Bernardi, F., Bono, A., Danecek, P., Faenza, L., Fares, M., Lauciani, V., Lucente, F.P., Marcocci, C., Pietrangeli, D., Quintiliani, M., Mazza, S., Michelini A. (2016). INGV data lifecycle management system performances during Mw 6.0 2016 Amatrice Earthquake Sequence, Ann. Geophyiscs, this issue.

Pondrelli, S. et al. (2016). Pianificazione e gestione di un'emergenza sismica: esercitazione INGV del 26 novembre 2015 effettuata nell'ambito della Linea di Attività T5 "Sorveglianza sismica e operatività post terremoto", Quaderni di Geofisica, 137.

Scafidi, D., Spallarossa, D., Turino, C., Ferretti, G. and Viganò, A. (2016). Automatic P-and SWave Local Earthquake Tomography: Testing Performance of the Automatic Phase-Picker Engine RSNI-Picker, Bull. Seism. Society of America, $\quad 106 \quad$ (2), 526-536. Doi:10.1785/0120150084.

Spallarossa, D., G., Ferretti, D., Scafidi, C., Turino and M., Pasta (2014). Performance of the RSNI-Picker, Seismol. Res. Lett. 85, 1243-1254.

QUEST working group (2016). The 24 August 2016 Amatrice earthquake: macroseismic survey in the damage area and EMS intensity assessment, Ann. Geophyiscs, this issue. DOI: $10.4401 /$ ag-7203. 